\title{
Impact of Addition of FGDB as a Soil Amendment on Physical and Chemical Properties of an Alkali Soil and Crop Yield of Maize in Northern China Coastal Plain
}

\author{
H.-L. Yu, ${ }^{1,2,3}$ W. Gu, ${ }^{1}$ J. Tao, ${ }^{1}$ J.-Y. Huang, ${ }^{3,4}$ and H.-S. Lin $^{3}$ \\ ${ }^{1}$ The State Key Laboratory of Earth Surface Process and Resource Ecology, Beijing Normal University, Beijing 100875, China \\ ${ }^{2}$ College of Resources and Environment, Ningxia University, Yinchuan 750021, China \\ ${ }^{3}$ College of Agricultural Sciences, The Pennsylvania State University, State College, PA 16803, USA \\ ${ }^{4}$ Center of New Technology Application and Research, Ningxia University, Yinchuan 750021, China
}

Correspondence should be addressed to H.-L. Yu; yhl@nxu.edu.cn

Received 25 August 2014; Revised 16 November 2014; Accepted 26 November 2014

Academic Editor: Grigorios Itskos

Copyright (C) 2015 H.-L. Yu et al. This is an open access article distributed under the Creative Commons Attribution License, which permits unrestricted use, distribution, and reproduction in any medium, provided the original work is properly cited.

\begin{abstract}
To evaluate the effect of Flue gas desulfurization byproduct( FGDB )as a soil amendment on growth and yield of maize (Zea mays) and to determine the impact of FGDB additions on soil fertility characteristics in alkaline clayey soils, a 2-year field experiment was conducted in Huanghua, in Northern China Coastal Plain. The experiment included five treatments in which the soil was amended with FGDB at $15 \mathrm{~cm}$ depth at the rates of $0 \mathrm{t} \cdot \mathrm{hm}^{-2}, 4.50 \mathrm{t} \cdot \mathrm{hm}^{-2}, 9.00 \mathrm{t} \cdot \mathrm{hm}^{-2}, 13.5 \mathrm{t} \cdot \mathrm{hm}^{-2}$, and $18.00 \mathrm{t} \cdot \mathrm{hm}^{-2}$, respectively, before maize was planted. The values of soil $\mathrm{pH}$, exchangeable sodium percentage (ESP), and bulk density (BD) of the soil decreased; however, values of electrical conductivity (EC), water holding capacity (WHC), and plant nutrients increased with FGDB application in the soil. Crop plants grow more readily in FGDB amended soils because of improved soil properties. The best ameliorative effect was obtained at the rate of $13.5 \mathrm{t} \cdot \mathrm{hm}^{-2}$. The germination percentage, plant height, and crop yield successively increased in both years. The results indicated FGDB was an effective soil amendment for improving the physicochemical properties and nutrient balance, and enhancing crop germination, growth, and yield, particularly when applied at a suitable application rate.
\end{abstract}

\section{Introduction}

Salinization and alkalinization of soil are a widespread environmental problem. Alkaline-saline soils are widely distributed across the world, covering an area of $9.5 \times 10^{6} \mathrm{~km}^{2}$, accounting for $7.3 \%$ of the Earth's land surface [1]. About $23 \%$ of the world's currently cultivated land area $\left(1.5 \times 10^{9} \mathrm{ha}\right)$ is saline and another $37 \%$ is alkaline. Soil degradation caused by salinization and alkalinization is of universal concern. In the northwestern, northern, northeastern, and coastal area of China, there are $346,000 \mathrm{~km}^{2}$ saline and alkali soil, $1 / 3$ of which are alkali soil $\left(92,000 \mathrm{~km}^{2}\right.$ or 22.7 million acres). Alkalization and salinization of soils are important factors limiting agricultural productivity [2]. These soils are unproductive, impermeable, and hard due to the presence of undesirable salts on the surface.
The salinization and alkalinization of the soil in the coastal area of China are very serious. Crop yields in Bo Sea coastal plain of China are limited by the high soil alkalinity, which is common to this region. The chief characteristic of alkaline soils from agricultural standpoint is that they contain excessive quantities of exchangeable sodium and appreciable amounts of soluble sodium carbonate to adversely affect the growth of most crop plants. Alkali soils are characterized by exchangeable $\mathrm{Na}^{+}$(more than 15\%), low quantities of $\mathrm{Ca}^{2+}$, and $\mathrm{pH}$ values that usually range between 8.5 and 10.5. Excess exchangeable sodium has an adverse effect on the physical and nutritional properties of the soil. Plant growth in alkaline soils is adversely affected chiefly by the dispersive effect of excess exchangeable sodium resulting in poor physical soil properties and the effect of high soil $\mathrm{pH}$ on nutritional imbalance including a deficiency of calcium. 
Due to the poor physical properties, most alkaline clayey soil belongs to the middle and low-yield soils. Several techniques have been developed to improve the physical conditions, such as soil amendment using organic manures and industrial wastes. Improvement of alkaline soils essentially requires the replacement of sodium in the soil exchange complex by calcium through use of soil amendments and leaching and drainage of salts resulting from reaction of amendments with exchangeable sodium.

Saline wastelands have been successfully reclaimed for corn growth in Bo Sea coastal plain of China in recent years [3]. The primary management strategies adopted to accomplish this include the application of FGDB amendment on saline wasteland, which combines industrial waste recycling with agricultural soil improvement [4]. In this case, more FGDB requirement should be applied to replace the exchangeable $\mathrm{Na}^{+}$required to neutralize all the soluble sodium carbonate in the soil.

Flue gas desulfurization byproducts (FGDBs) are often marketed as a soil conditioner for improving soil tillage. Considerable amounts of coal combustion products are generated when coal is burned for generation of electricity. In China about $80 \%$ of electricity is generated by coal-based thermal power plant, which produces more than $1000 \mathrm{mt}$ FGDB per annum as a byproduct that creates the problem of its ecofriendly disposal. Most coal combustion products in China are presently discarded, especially in landfills, and landfill sites are becoming more limited and disposal costs continue to increase. To meet Clean Air Standards, wet scrubber technology currently used removes much of the $\mathrm{SO}_{2}$ to form large amounts of flue gas desulfurization byproducts (FGDBs) $[5,6]$. However, FGDB is also known as a potential environmental pollutant at both regional and global levels [7]. Thus, the use of FGDB as substitutes for agricultural limestone represents a potential beneficial use alternative to landfill disposal of these materials.

Many experiments and studies on the effect and potentiality of FGDB as an amendment in agricultural applications have been conducted by various agencies and research institutes at dispersed locations all over the world [8-12]. Its use in agriculture is mainly based on its liming potential and supply of nutrients which promote growth of plants and alleviate the condition of nutrient deficiency in soils [13-16]. The main component of FGDB is calcium sulfate $\left(\mathrm{CaSO}_{4}\right)$. However, FGDB is a useful ameliorant that may improve the physical, chemical, and biological properties of problem soils and is a source of readily available plant macro- and micronutrients [17]. Compared to most other calcium-rich soil amendments, such as limestone, FGDB is relatively soluble in water, dissolving up to 2 g per liter $[18,19]$. The solubility of FGDB, when either incorporated or surface applied, permits a quick release of calcium $\left(\mathrm{Ca}^{2+}\right)$ and sulfate $\left(\mathrm{SO}_{4}{ }^{2-}\right)$ ions into the soil solution. The supply of dissolved salt and $\mathrm{Ca}^{2+}$ ions, in particular, may reduce soil crusting and otherwise benefit soil structure. The aggregation of clay particles that help to form and stabilize soil structure is clearly enhanced by the presence of calcium on clay exchange sites.

Many researchers have already proposed that relatively low dose of FGDB as soil amendment improves the physical and chemical properties of the soil, for example, soil $\mathrm{pH}$, bulk density, texture, water holding capacity, electrical conductivity, and so on [20]. As a consequence, the growth and yield of crops also were increased significantly.

It has been suggested that FGDB could be a useful amendment for alkaline soils and has positive effects on soil improvement and crop production because of high concentrations of sorbent components and significant neutralization potential [21-23]. For example, beneficial agricultural uses of FGDB application as amendment to alkaline soil to mitigate high $\mathrm{pH}$ problems provide plant nutrients, improve soil physical properties, help alleviate soil compaction, and improve aggregate stability of alkaline soils [24,25].

There is no clear guidance with regard to the application rate of FGDB as soil amendment. In order to make efficient use of FGDB to enhance crop production, it is necessary to be able to determine the amount of FGDB that should be applied.

Keeping all these in mind, the present experiment has been designed to investigate the impact of the different application rates of FGDB amendments on the soil properties and the growth and yield of maize on the alkaline soils of the coastal wasteland. The specific objectives were to (1) determine the efficacy of FGDB ash as a soil amendment; (2) evaluate FGDB ash as a source of $\mathrm{Ca}$ and other nutrients for crops; (3) understand the feasibility of FGDB in the alkaline waste land reclamation without affecting the production of maize; (4) determine the appropriate FGDB application rate that should be applied on condition of certain soil and crop. Due to the increasing solid waste under Chinese scenario, the management of FGDB as soil amendment can give us a better reference for the better disposal of solid waste.

\section{Materials and Methods}

2.1. Experimental Site. The field experiments were carried out during 2011 and 2012 in Huanghua, Hebei, China. The station $\left(38^{\circ} 22^{\prime} \mathrm{N}, 117^{\circ} 21^{\prime} \mathrm{E}\right)$ is in the eastern part of the North China Plain. The climate of the area is temperate monsoon. Because of monsoon influence, rainfall is highly variable in this region. Annual average precipitation is $627 \mathrm{~mm}$, of which $70-$ $80 \%$ is during July-September [26]. The average evaporation in this region is $1989 \mathrm{~mm}$, up to 4-5 times the annual average precipitation. Annual average temperature is $12.1^{\circ} \mathrm{C}$. Seasonal drought is frequent in spring and autumn, and $90 \%$ of springs experience drought; the soluble salts accumulate in the upper soil profile. The groundwater level changes from 1 to $3.5 \mathrm{~m}$. The dominant soils in the coastal plain are characterized by having high $\mathrm{pH}$ values and alkalinity, being clay-rich, being of slow permeability class, and being dominated by clay with less sand and silt fractions. The major salts are $\mathrm{Nacl}$ and $\mathrm{NaHCO}_{3}$ [27].

Before treatments, surface soil samples at two different depths $(0-10 \mathrm{~cm}$ and $10-20 \mathrm{~cm})$ were collected, air-dried, and analyzed to determine fertility status, $\mathrm{pH}, \mathrm{FGDB}$ requirements, and concentrations of elements essential for growth of higher plants. Some selected soil physical, chemical, and mineralogical properties are listed in Tables 1, 2, and 3. 
TABLE 1: Basic soil properties of the initial soil profile.

\begin{tabular}{|c|c|c|c|c|c|c|c|c|}
\hline \multirow{2}{*}{ Soil layers } & \multicolumn{3}{|c|}{ Soil mechanical composition (\%) } & \multirow{2}{*}{$\mathrm{ECe}(\mathrm{ms} / \mathrm{m})$} & \multirow{2}{*}{$\mathrm{pH}$} & \multirow{2}{*}{$\begin{array}{l}\text { Soil bulk density } \\
\qquad\left(\mathrm{g} \mathrm{cm}^{-3}\right)\end{array}$} & \multirow{2}{*}{ Soil texture } & \multirow{2}{*}{ Soil color } \\
\hline & $<0.002 \mathrm{~mm}$ & $0.002-0.05 \mathrm{~mm}$ & $0.05-2 \mathrm{~mm}$ & & & & & \\
\hline $0-10 \mathrm{~cm}$ & 57.37 & 34.12 & 8.51 & 0.436 & 8.74 & 1.35 & Clay & Dirty white \\
\hline $10-20 \mathrm{~cm}$ & 64.66 & 31.23 & 4.11 & 0.296 & 8.91 & 1.43 & Clay & Grayish \\
\hline
\end{tabular}

Values are average of triplicate measurements.

TABLE 2: Basic chemical properties of the initial alkaline soil.

\begin{tabular}{lc}
\hline Parameter & Value \\
\hline Organic matter $(\%)$ & $1.41 \pm 0.09$ \\
$\mathrm{pH}$ & $8.59 \pm 0.14$ \\
$\mathrm{EC}\left(\mathrm{mMho} \mathrm{cm}^{-1}\right)$ & $0.43 \pm 0.003$ \\
Total N (\%) & $0.23 \pm 0.004$ \\
Available P (cmol kg & $4.16 \pm 0.06$ \\
$\mathrm{~K}\left(\mathrm{cmol} \mathrm{kg}{ }^{-1}\right.$ soil) & $0.110 \pm 0.017$ \\
$\mathrm{Na}\left(\mathrm{cmol} \mathrm{kg}^{-1}\right.$ soil) & $3.32 \pm 0.02$ \\
$\mathrm{Ca}\left(\mathrm{cmol} \mathrm{kg}^{-1}\right.$ soil) & $1.26 \pm 0.06$ \\
$\mathrm{Mg}\left(\mathrm{cmol} \mathrm{kg}^{-1}\right.$ soil) & $1.02 \pm 0.05$ \\
$\mathrm{SO}_{4}\left(\mathrm{cmol} \mathrm{kg}^{-1}\right.$ soil) & $3.67 \pm 0.05$ \\
$\mathrm{ESP}(\%)$ & $16.30 \pm 0.16$ \\
\hline
\end{tabular}

Values are mean \pm standard deviation of triplicate measurements.

TABLE 3: Basic mineralogical properties of the initial alkaline soil.

\begin{tabular}{lc}
\hline Parameter & Content (\%) \\
\hline Primary mineral & \\
$\quad$ Quartz & $9.2 \pm 0.25$ \\
Mica & $9.5 \pm 0.33$ \\
Feldspar & $22.1 \pm 1.26$ \\
Clay mineral & \\
Smectite & $19.4 \pm 1.06$ \\
Illite & $14.7 \pm 1.00$ \\
Potash feldspar & $9.7 \pm 0.78$ \\
Albite & $9.0 \pm 0.55$ \\
Kaolinite & $5.3 \pm 0.16$ \\
\hline
\end{tabular}

Values are mean \pm standard deviation of triplicate measurements.

2.2. Experimental Design. The FGDB $(\mathrm{pH}=7.2)$ was obtained from Dagang Electricity Plant, Tianjin. Some selected physical, chemical, and mineralogical properties of FGDB are listed in Tables 4 and 5. The crop species used in the experiments was maize (Zea mays). The experiment field was cleared of any weeds and senesced plant material before the establishment of plots. Plot sizes were designed by $6 \mathrm{~m} \times$ $8 \mathrm{~m}$ each and were arranged in a randomized block design with five replications. The two crops were planted in $40 \mathrm{~cm}$ rows at a population of 400 seeds per plot on April 20, 2011. In order to find the optimum FGDB application rate for maize in Bo Sea coastal plain of China, we set up the five FGDB application rates treatments in this study. The amount of FGDB required for the field trials was determined from treatment application rates and the plot areas for each treatment. Before seeding, the FGDB were applied at rates equivalent to $0 \mathrm{t} \cdot \mathrm{hm}^{-2}, 4.50 \mathrm{t} \cdot \mathrm{hm}^{-2}, 9.00 \mathrm{t} \cdot \mathrm{hm}^{-2}, 13.5 \mathrm{t} \cdot \mathrm{hm}^{-2}$, and $18.00 \mathrm{t} \cdot \mathrm{hm}^{-2}$, respectively, hereafter denoted as T0, T1, T2, T3, and T4. T0 is the unamended control treatment. FGDB treatments were applied to the crops plots at $15 \mathrm{~cm}$ depth by filling a wheelbarrow with FGDB, transporting the wheelbarrow load to the plot and distributing the FGDB evenly over the plot area using small plastic pails. In 2012, the applications were repeated in the same way.

2.3. Plant Management and Measurements. Plant seedlings productivity was recorded on the 15th day after seeding. Weeds were controlled by postemergence application of herbicide. Seed germination is usually used to screen crops for their tolerances to soil alkalinity. This experiment was performed to evaluate the effects on the germination rate of seeds in soil amended with FGDB. 400 seedlings of maize were planted in each plot with different application rates of FGDB amended soils. A total of 50 plots were used in this experiment. Seedlings were monitored by calculating seed germination percentages 2 weeks after planting. At day 15 , all the plants have germinated and the percentage of germination was counted. Plant height was measured by elongating the plant and measuring to the top of the upper leaf with a ruler at day 100 of each year. At day 180 of each year, plots were harvested. Yield was measured by open-air drying for 30 days; after that the dry weights were measured gravimetrically.

2.4. Soil Sampling and Analysis. To determine the original soil properties, three composite soil samples were collected from the entire experimental area at two depths $(0-10 \mathrm{~cm}$ and $10-20 \mathrm{~cm}$ ) prior to treatment establishment, and properties are reported in Table 1 . Soil cores were obtained from each plot using an auger $(2.0 \mathrm{~cm}$ in diameter and $15 \mathrm{~cm}$ high) on April 2 (before seeding) and October 6 (after harvest) in 2011 and on April 5 (before seeding) and October 10 (after harvest) in 2012. The samples were obtained from two different depths, that is, $0-10$ and $10-20 \mathrm{~cm}$ deep. The three replicate soil samples were mixed into one sample per treatment. All soil samples were air-dried and passed through a $1 \mathrm{~mm}$ sieve. Soluble salt estimates and soil $\mathrm{pH}$ were based on extracts of saturated soil. Soil pH, electrical conductivity (EC), organic matter, cation exchange capacity (CEC), and texture were determined by using standard laboratory procedures. Water holding capacity (WHC) and bulk density (BD) were measured by the methods of Black [28]. Exchangeable $\mathrm{Na}^{+}, \mathrm{K}^{+}$, $\mathrm{Mg}^{2+}$, and $\mathrm{Ca}^{2+}$ were extracted in ammonium acetate by repeated leaching methodology and the extracts were kept separately for their determination [29]. The content of $\mathrm{N}$ was 
TABLE 4: Some mineralogical and physical properties of FGDB used to amend alkaline soil.

\begin{tabular}{lccccccc}
\hline Mineral component & Water content (\%) & $\mathrm{CaSO}_{4} \cdot 2 \mathrm{H}_{2} \mathrm{O} \%$ & \multicolumn{2}{c}{ Particle size $\%$} \\
$30-60 \mu \mathrm{m}$ & $>60 \mu \mathrm{m}$ & Texture & Insoluble residue (\%) \\
\hline Gypsum and quarts & 10 & 99 & 3.2 & 0.14 & 96.66 & Silt sized & 1 \\
\hline
\end{tabular}

Average of triplicate measurements.

TABLE 5: Some chemical properties of FGDB used to amend alkaline soil.

\begin{tabular}{lcccccccccc}
\hline Components & $\mathrm{SO}_{3}$ & $\mathrm{CaO}$ & $\mathrm{MgO}$ & $\mathrm{Al}_{2} \mathrm{O}_{3}$ & $\mathrm{Cl}$ & $\mathrm{Na}_{2} \mathrm{O}$ & $\mathrm{K}_{2} \mathrm{O}$ & $\mathrm{P}_{2} \mathrm{O}_{5}$ & $\mathrm{Heavy}$ metals \\
\hline Contents & 48.52 & 34.12 & 2.11 & 1.00 & 0.57 & 0.27 & 0.11 & 1.12 & 1.08 \\
\hline
\end{tabular}

Average of triplicate measurements.

assessed following modified Kjeldahl method and $\mathrm{P}$ and $\mathrm{K}$ were analyzed by spectrophotometer and flame photometer after acid digestion. The concentrations of heavy metals were obtained by EPA method 3050 [30]. In this study, ECe is the abbreviation of electrical conductivity of saturated-soil extract. Cation exchange capacity (CEC) and exchangeable sodium percentage (ESP) were calculated with the help of following equations:

$$
\begin{aligned}
& \mathrm{CEC}=\sum\left(\mathrm{Mg}, \mathrm{K}, \mathrm{Na}, \mathrm{Ca}, \mathrm{NH}_{4}, \mathrm{H}, \mathrm{Al}\right), \\
& \mathrm{ESP}=\frac{\text { Exchangeable } \mathrm{Na}}{\text { cation exchange capacity }} * 100 .
\end{aligned}
$$

The ECe (electrical conductivity of saturated-soil extract) of the soil at a depth of $20 \mathrm{~cm}$ is $0.453 \mathrm{mS} / \mathrm{m}$ (Table 1), which is high for crops. The color of alkaline soil was dirty white to grayish and was of clay-type soil texture. The $\mathrm{pH}$ of the tested soil ranged from 8.74 to 8.91 . The water holding capacity was $45 \%$. The exchangeable $\mathrm{Ca}^{2+}$ and $\mathrm{Na}^{+}$were 0.35 and $0.78 \%$, respectively. Some selected soil properties such as soil texture, soil bulk density, ECe, and $\mathrm{pH}$ are listed in Table 1.

2.5. Statistical Analysis. The results obtained for each of the dependent variables in this study were analyzed statistically using a model that included treatment and replication as independent variables. All the statistical tests were performed using SPSS software (SPSS Inc., version 16.0).

\section{Results}

3.1. Chemical and Physical Properties of FGDB. The result showed that FGDB used in the present study was relatively alkaline $(\mathrm{pH}=7.5)$ and rich in soluble salts. The FGDB used in the present contained $10 \%$ free water and had a loose and uniform structure and a particle size of 30-60 $\mu \mathrm{m}$ (Table 4). Similar to natural gypsum, the major component is calcium sulfate $\left(\mathrm{CaSO}_{4}\right)$; additional components include $\mathrm{Na}_{2} \mathrm{O}, \mathrm{K}_{2} \mathrm{O}$, $\mathrm{MgO}, \mathrm{Cl}, \mathrm{P}_{2} \mathrm{O}_{5}$, and heavy metals $[31,32]$. Chemical analyses of the FGDB collected in this study showed that heavy metals were presented at low concentrations (Table 5). The metal contents were much lower than concentration limits identified by government regulations for land application [33]. FGDB has a low bulk density, high surface area, and light texture $[17,34]$. Some selected properties of the FGDB are provided in Tables 4 and 5.

\subsection{FGDB to Improve Soil Physical Properties}

3.2.1. Particle Size Analysis. The soil at the Huanghua research site is characterized by being clay-rich and having high soil $\mathrm{pH}$ value and slow permeability. The texture analysis revealed that the experimental soil had clay texture having $57.37 \%$ clay, $34.12 \%$ silt, and $8.51 \%$ sand, respectively. Greater silt contents are observed at the lower depths in FGDB amended soils (Table 6). Clay content does not vary greatly between deeper horizons. Differences in particle size analysis among three horizons result from changes in the silt and clay fractions. At the same time, improved soil texture of the upper layer of FGDB amended soils result from application of silt-sized FGDB. Application of FGDB can reduce clay dispersion and promote flocculation of soils. Results of particle size analysis (Table 6) showed that clay fractions dominated the soil texture for the experimental field. The USDA textural grouping was clayey for the two depths. All the four FGDB application rates showed the potential of improving soil texture. Application of higher rates of T3 and T4 can change the surface texture of soils, by increasing the silt content. As would be expected, the coarser fractions (sands and coarse silt) increased and the finer fractions decreased with depth.

In both years, silt percentage due to FGDB application showed a significant increase over control. In 2011, a trend was observed in the surface soil layer $(0-10 \mathrm{~cm}$ depth) with increasing dosage of FGDB an increase over control values for silt, from $37.15,38.44,40.13$, and 41.62 at the application rates of T1, T2, T3, and T4, respectively. And a similar trend was observed at the deeper soil layer $(10-20 \mathrm{~cm}$ depth) with increasing dosage of FGDB an increase from control values for silt, from 43.12, 45.64, 46.87, and 48.45 at the application rates of T1, T2, T3, and T4, respectively. In 2012, similarly, silt content showed an increase trend in both layers at all application rates. But the optimum increments were observed at T3 treatment unlike in 2011. It indicated that continuous high application rate of FGDB may have adverse effect on soil texture.

3.3. Bulk Density (BD) and Water Holding Capacity (WHC). In both years, we collected soil sample after harvest and 
TABLE 6: Soil texture of experimental plots (USDA classification).

\begin{tabular}{|c|c|c|c|c|c|c|c|c|}
\hline \multirow[b]{2}{*}{$\begin{array}{l}\text { Size fraction for } \\
\text { depth interval }\end{array}$} & \multicolumn{4}{|c|}{$0-10 \mathrm{~cm}$} & \multicolumn{4}{|c|}{$10-20 \mathrm{~cm}$} \\
\hline & $\begin{array}{c}\text { Sand } \\
(\%)\end{array}$ & $\begin{array}{l}\text { Silt } \\
(\%)\end{array}$ & $\begin{array}{l}\text { Clay } \\
(\%)\end{array}$ & $\begin{array}{c}\text { Increase over } \\
\text { silt (silt 34.12\%) }\end{array}$ & $\begin{array}{l}\text { Sand } \\
(\%)\end{array}$ & $\begin{array}{l}\text { Silt } \\
(\%)\end{array}$ & $\begin{array}{l}\text { Clay } \\
(\%)\end{array}$ & $\begin{array}{c}\text { Increase over } \\
\text { silt (silt 31.23\%) }\end{array}$ \\
\hline \multicolumn{9}{|l|}{2011} \\
\hline T0 & 8.51 & 34.12 & 57.37 & 0 & 4.11 & 31.23 & 64.66 & 0 \\
\hline $\mathrm{TI}$ & 8.64 & 37.15 & 54.21 & 3.03 & 4.53 & 43.12 & 52.35 & 11.89 \\
\hline $\mathrm{T} 2$ & 8.53 & 38.44 & 53.03 & 4.32 & 4.62 & 45.64 & 49.74 & 14.41 \\
\hline T3 & 8.47 & 40.13 & 51.4 & 6.01 & 5.84 & 46.87 & 47.29 & 15.64 \\
\hline $\mathrm{T} 4$ & 8.54 & 41.62 & 49.84 & 7.5 & 6.12 & 48.45 & 45.43 & 17.22 \\
\hline \multicolumn{9}{|l|}{2012} \\
\hline T0 & 8.53 & 36.34 & 55.13 & 2.22 & 4.33 & 36.23 & 59.44 & 5 \\
\hline TI & 8.79 & 39.46 & 51.75 & 5.34 & 4.53 & 47.12 & 48.35 & 15.89 \\
\hline $\mathrm{T} 2$ & 8.83 & 39.64 & 51.53 & 5.52 & 5.32 & 49.64 & 45.04 & 18.41 \\
\hline T3 & 8.56 & 44.83 & 46.61 & 10.71 & 6.15 & 49.96 & 43.89 & 18.73 \\
\hline $\mathrm{T} 4$ & 8.69 & 44.78 & 46.53 & 10.66 & 6.89 & 51.46 & 41.65 & 20.23 \\
\hline
\end{tabular}

Average of triplicate measurements.

TABLE 7: Treatment effect on surface soil (0-10 cm depth) BD (bulk density), WHC (water holding capacity), and OM (organic matter) in 2011 and 2012.

\begin{tabular}{lcccccc}
\hline & Year & T0 & T1 & T2 & T3 & T4 \\
\hline \multirow{2}{*}{ BD $\left(\mathrm{g} \mathrm{cm}^{-3}\right)$} & 2011 & 1.37 & 1.34 & 1.32 & 1.24 & 1.19 \\
& 2012 & 1.43 & 1.31 & 1.29 & 1.18 & 1.16 \\
\hline \multirow{2}{*}{ WHC (\%) } & 2011 & 46.1 & 49.9 & 53.6 & 64.9 & 66.3 \\
& 2012 & 47.4 & 51.3 & 63.2 & 71.2 & 75.3 \\
\hline \multirow{2}{*}{ OM (\%) } & 2011 & 1.41 & 1.53 & 1.56 & 1.52 & 1.49 \\
& 2012 & 1.43 & 1.55 & 1.70 & 1.56 & 1.69 \\
\hline
\end{tabular}

Average of triplicate measurements.

found that all bulk densities were significantly lower for the FGDB treatments at all the four application rates compared with bulk densities of the control. Even though the statistical report indicated a marked difference between control and other application rates, no significant difference was reported between $\mathrm{T} 3$ and $\mathrm{T} 4$, suggesting that at or over the rate $\mathrm{T} 3 \mathrm{~h}$ has a similar effect. Hence, the optimum rate of FGDB application to improve soil bulk density was $13.5 \mathrm{thm}^{-2}$. In the control, the relatively high soil BD is consistent with the observed clay high fraction, low sand fraction, and exceptionally low OM content (Table 7). This condition is typical for local alkaline clay textured soils, which have potentially low infiltration, decreased aggregation, and lower water holding capacities.

To test the effect of FGDB on the soils' water holding capacity (WHC), WHC of the unamended soils and soils treated with FGDB was determined. In comparison with the control soil, the $4.50 \mathrm{thm}^{-2}, 9.00 \mathrm{thm}^{-2}, 13.5 \mathrm{thm}^{-2}$, and $18.00 \mathrm{thm}^{-2}$ FGDB amended soils showed a 8.24, 16.26, 40.78 , and $43.81 \%$ higher water holding capacity in 2011, respectively. Similarly, in 2012, there was another increase of $7.6,25,33.42$, and $37.05 \%$, respectively, compared with the control. However, the rate of increase is slowed after $13.5 \mathrm{thm}^{-2}$. For all treatments, increasing the application rate from 4.5 to $18.00 \mathrm{thm}^{-2}$ increased the WHC, whereas increasing the application rate to $13.5 \mathrm{t} \mathrm{hm}^{-2}$ brought WHCs up to values that are higher than at any of the other application rates, which was suggesting that the optimum rate of FGDB application to improve WHC was $13.5 \mathrm{t} \mathrm{hm}^{-2}$.

\subsection{FGDB to Improve Soil Chemical Properties}

3.4.1. Soil $p H$. The soil $\mathrm{pH}$ data from plots established on this initially very alkaline soil demonstrates the significant alkaline neutralizing capacity of FGDB. The effect of modifying soil $\mathrm{pH}$ by FGDB as amendment showed persistent changes with respect to the rate of application and duration of experiment. Compared with the control, a dose-dependent and progressive decrease in soil $\mathrm{pH}$ was observed. The soil $\mathrm{pH}$ values, however, were significantly affected when the soil was amended with FGDB. At 0-10 cm depth, within the first year of application, soil $\mathrm{pH}$ decreased from 8.6 for the control to the maximum of 7.74 at T3 treatment at rate of $13.5 \mathrm{thm}^{-2}$, which is considered suitable for nutrient availability and crop growth ( $\mathrm{pH}$ 7.5-8.5). In terms of soil $\mathrm{pH}$ adjustment, apart from initially higher alkalinity in the FGDB treatments, the target soil $\mathrm{pH}$ range $(\mathrm{pH} 7.5-8.5)$ was achieved within the first year in all four FGDB application rates (Figure 1). And in 2012, the second year, a continuous decrease in soil pH was observed in all FGDB amended treatments, similarly with the biggest decrease occurring in T3. And no further increases in $\mathrm{pH}$ were observed for subsoil. The data indicated that the effect of modifying soil $\mathrm{pH}$ occurred primarily within the treatment zone. Results obtained in this study are consistent with the large body of literature which indicates that FGDB can act as an effective liming agent to neutralize solution $\mathrm{pH}$ and reduce exchangeable alkalinity values.

3.5. EC. It is obvious that, after applying FGDB in alkaline clayey soil, soluble salts in FGDB were dispersed into the 
TABLE 8: Selected chemical properties and nutrient $\left(\mathrm{cmol} \mathrm{kg}^{-1}\right)$ concentrations of different FGDB amended soils.

\begin{tabular}{|c|c|c|c|c|c|c|}
\hline & & T0 & $\mathrm{T} 1$ & $\mathrm{~T} 2$ & $\mathrm{~T} 3$ & $\mathrm{~T} 4$ \\
\hline \multirow{3}{*}{ 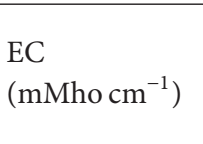 } & $\mathrm{d} 0$ & $0.43 \pm 0.003^{\mathrm{a}}$ & $0.43 \pm 0.003^{\mathrm{a}}$ & $0.43 \pm 0.003^{\mathrm{a}}$ & $0.43 \pm 0.003^{\mathrm{a}}$ & $0.43 \pm 0.003^{\mathrm{a}}$ \\
\hline & $\mathrm{d} 1$ & $0.44 \pm 0.002^{\mathrm{a}}$ & $0.46 \pm 0.003^{\mathrm{a}}$ & $0.49 \pm 0.003^{\mathrm{b}}$ & $0.51 \pm 0.002^{c}$ & $0.53 \pm 0.005^{\mathrm{d}}$ \\
\hline & $\mathrm{d} 2$ & $0.46 \pm 0.003^{\mathrm{a}}$ & $0.47 \pm 0.004^{\mathrm{a}}$ & $0.51 \pm 0.005^{\mathrm{b}}$ & $0.53 \pm 0.004^{c}$ & $0.55 \pm 0.006^{\mathrm{d}}$ \\
\hline \multirow{3}{*}{ Total N (\%) } & $\mathrm{d} 0$ & $0.23 \pm 0.004^{\mathrm{a}}$ & $0.23 \pm 0.004^{\mathrm{a}}$ & $0.23 \pm 0.004^{\mathrm{a}}$ & $0.23 \pm 0.004^{\mathrm{a}}$ & $0.23 \pm 0.004^{\mathrm{a}}$ \\
\hline & $\mathrm{d} 1$ & $0.26 \pm 0.004^{\mathrm{a}}$ & $0.29 \pm 0.005^{\mathrm{b}}$ & $0.33 \pm 0.002^{c}$ & $0.34 \pm 0.004^{\mathrm{c}}$ & $0.37 \pm 0.002^{\mathrm{d}}$ \\
\hline & $\mathrm{d} 2$ & $0.27 \pm 0.003^{\mathrm{a}}$ & $0.31 \pm 0.001^{\mathrm{b}}$ & $0.35 \pm 0.004^{c}$ & $0.36 \pm 0.002^{c}$ & $0.40 \pm 0.004^{\mathrm{d}}$ \\
\hline \multirow{3}{*}{$\begin{array}{l}\text { Available P } \\
\left(\mathrm{cmol} \mathrm{kg}^{-1} \text { soil }\right)\end{array}$} & $\mathrm{d} 0$ & $4.16 \pm 0.06^{\mathrm{a}}$ & $4.16 \pm 0.06^{\mathrm{a}}$ & $4.16 \pm 0.06^{\mathrm{a}}$ & $4.16 \pm 0.06^{\mathrm{a}}$ & $4.16 \pm 0.06^{\mathrm{a}}$ \\
\hline & $\mathrm{d} 1$ & $4.64 \pm 0.05^{\mathrm{a}}$ & $5.61 \pm 0.07^{\mathrm{b}}$ & $5.92 \pm 0.04^{\mathrm{c}}$ & $6.42 \pm 0.06^{\mathrm{d}}$ & $6.55 \pm 0.02^{\mathrm{d}}$ \\
\hline & $\mathrm{d} 2$ & $4.87 \pm 0.10^{\mathrm{a}}$ & $5.85 \pm 0.05^{\mathrm{b}}$ & $6.10 \pm 0.06^{c}$ & $6.56 \pm 0.05^{\mathrm{d}}$ & $6.61 \pm 0.07^{\mathrm{d}}$ \\
\hline \multirow{3}{*}{$\begin{array}{l}\mathrm{K} \\
\left(\mathrm{cmol} \mathrm{kg}^{-1} \text { soil }\right)\end{array}$} & $\mathrm{d} 0$ & $0.110 \pm 0.017^{\mathrm{a}}$ & $0.114 \pm 0.012^{\mathrm{a}}$ & $0.107 \pm 0.015^{\mathrm{a}}$ & $0.108 \pm 0.013^{\mathrm{a}}$ & $0.113 \pm 0.010^{\mathrm{a}}$ \\
\hline & $\mathrm{d} 1$ & $0.102 \pm 0.008^{\mathrm{a}}$ & $0.049 \pm 0.009^{c}$ & $0.068 \pm 0.010^{\mathrm{b}}$ & $0.051 \pm 0.008^{c}$ & $0.071 \pm 0.003^{\mathrm{b}}$ \\
\hline & $\mathrm{d} 2$ & $0.097 \pm 0.007^{\mathrm{a}}$ & $0.024 \pm 0.003^{\mathrm{c}}$ & $0.033 \pm 0.010^{c}$ & $0.032 \pm 0.002^{c}$ & $0.047 \pm 0.007^{b}$ \\
\hline \multirow{3}{*}{$\begin{array}{l}\mathrm{Na} \\
\left(\mathrm{cmol} \mathrm{kg}^{-1} \text { soil }\right)\end{array}$} & $\mathrm{d} 0$ & $3.32 \pm 0.02^{\mathrm{a}}$ & $3.28 \pm 0.07^{\mathrm{a}}$ & $3.35 \pm 0.09^{\mathrm{a}}$ & $3.34 \pm 0.04^{\mathrm{a}}$ & $3.29 \pm 0.09^{\mathrm{a}}$ \\
\hline & $\mathrm{d} 1$ & $3.25 \pm 0.06^{\mathrm{a}}$ & $2.41 \pm 0.08^{\mathrm{b}}$ & $1.85 \pm 0.05^{\mathrm{d}}$ & $2.19 \pm 0.01^{\mathrm{c}}$ & $2.46 \pm 0.08^{\mathrm{b}}$ \\
\hline & $\mathrm{d} 2$ & $3.17 \pm 0.07^{\mathrm{a}}$ & $1.32 \pm 0.04^{\mathrm{c}}$ & $1.24 \pm 0.06^{\mathrm{d}}$ & $1.53 \pm 0.02^{\mathrm{b}}$ & $1.50 \pm 0.09^{b}$ \\
\hline \multirow{3}{*}{$\begin{array}{l}\mathrm{Ca} \\
\left(\mathrm{cmol} \mathrm{kg}^{-1} \text { soil }\right)\end{array}$} & $\mathrm{d} 0$ & $1.26 \pm 0.06^{\mathrm{a}}$ & $1.32 \pm 0.09^{\mathrm{a}}$ & $1.27 \pm 0.05^{\mathrm{a}}$ & $1.23 \pm 0.04^{\mathrm{a}}$ & $1.30 \pm 0.07^{\mathrm{a}}$ \\
\hline & $\mathrm{d} 1$ & $1.31 \pm 0.09^{\mathrm{e}}$ & $2.05 \pm 0.11^{\mathrm{d}}$ & $4.11 \pm 0.24^{\mathrm{c}}$ & $5.93 \pm 0.53^{\mathrm{b}}$ & $11.75 \pm 0.79^{\mathrm{a}}$ \\
\hline & $\mathrm{d} 2$ & $1.19 \pm 0.05^{\mathrm{e}}$ & $1.82 \pm 0.09^{\mathrm{d}}$ & $3.66 \pm 0.18^{\mathrm{c}}$ & $4.89 \pm 0.30^{\mathrm{b}}$ & $8.27 \pm 0.67^{\mathrm{a}}$ \\
\hline \multirow{3}{*}{$\begin{array}{l}\mathrm{Mg} \\
\left(\mathrm{cmol} \mathrm{kg}^{-1} \text { soil }\right)\end{array}$} & $\mathrm{d} 0$ & $1.02 \pm 0.05^{\mathrm{a}}$ & $1.06 \pm 0.08^{\mathrm{a}}$ & $0.99 \pm 0.04^{\mathrm{a}}$ & $1.01 \pm 0.05^{\mathrm{a}}$ & $1.04 \pm 0.03^{\mathrm{a}}$ \\
\hline & $\mathrm{d} 1$ & $1.03 \pm 0.02^{c}$ & $1.83 \pm 0.01^{\mathrm{b}}$ & $2.01 \pm 0.04^{\mathrm{a}}$ & $2.03 \pm 0.05^{\mathrm{a}}$ & $2.10 \pm 0.07^{\mathrm{a}}$ \\
\hline & $\mathrm{d} 2$ & $0.95 \pm 0.03^{\mathrm{b}}$ & $1.42 \pm 0.04^{\mathrm{a}}$ & $1.47 \pm 0.05^{\mathrm{a}}$ & $1.53 \pm 0.03^{\mathrm{a}}$ & $1.55 \pm 0.06^{\mathrm{a}}$ \\
\hline \multirow{3}{*}{$\begin{array}{l}\mathrm{SO}_{4} \\
\left(\mathrm{cmol} \mathrm{kg}^{-1} \text { soil }\right)\end{array}$} & $\mathrm{d} 0$ & $3.67 \pm 0.05^{\mathrm{a}}$ & $3.58 \pm 0.04^{\mathrm{a}}$ & $3.71 \pm 0.02^{\mathrm{a}}$ & $3.60 \pm 0.04^{\mathrm{a}}$ & $3.69 \pm 0.03^{\mathrm{a}}$ \\
\hline & $\mathrm{d} 1$ & $3.56 \pm 0.04^{\mathrm{e}}$ & $4.52 \pm 0.07^{\mathrm{d}}$ & $7.71 \pm 0.08^{c}$ & $15.93 \pm 0.14^{\mathrm{b}}$ & $18.04 \pm 0.13^{\mathrm{a}}$ \\
\hline & $\mathrm{d} 2$ & $3.48 \pm 0.04^{\mathrm{d}}$ & $3.84 \pm 0.05^{\mathrm{d}}$ & $6.03 \pm 0.05^{\mathrm{c}}$ & $13.36 \pm 0.10^{b}$ & $15.69 \pm 0.09^{\mathrm{a}}$ \\
\hline \multirow{3}{*}{$\begin{array}{l}\text { ESP } \\
(\%)\end{array}$} & $\mathrm{d} 0$ & $16.30 \pm 0.16^{\mathrm{a}}$ & $14.28 \pm 0.18^{\mathrm{a}}$ & $14.37 \pm 0.17^{\mathrm{a}}$ & $14.28 \pm 0.23^{\mathrm{a}}$ & $14.35 \pm 0.14^{\mathrm{a}}$ \\
\hline & $\mathrm{d} 1$ & $16.47 \pm 0.20^{\mathrm{a}}$ & $8.83 \pm 0.10^{c}$ & $8.50 \pm 0.11^{\mathrm{c}}$ & $10.64 \pm 0.15^{b}$ & $10.58 \pm 0.18^{\mathrm{b}}$ \\
\hline & $\mathrm{d} 2$ & $14.26 \pm 0.15^{\mathrm{a}}$ & $6.08 \pm 0.08^{\mathrm{d}}$ & $6.01 \pm 0.13^{\mathrm{d}}$ & $8.34 \pm 0.10^{\mathrm{b}}$ & $7.72 \pm 0.05^{\mathrm{c}}$ \\
\hline
\end{tabular}

d0: initial; d1: at day 180 in 2011; d2: at day 180 in 2012.

Values $=$ mean \pm standard deviation of triplicate measurements.

Letters denote statistically significant differences across treatments $(P \leq 0.05)$.

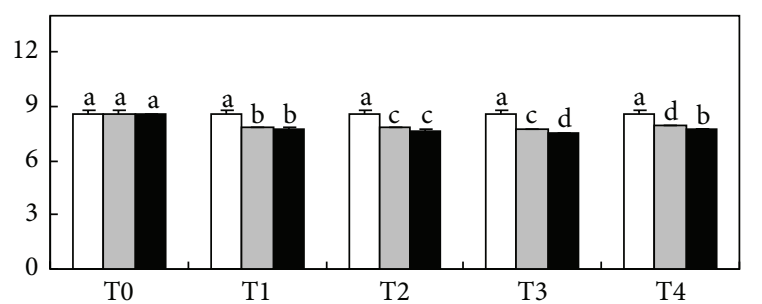

$\square$ d0: initial

$\square \mathrm{d} 1$ : at day 180 in 2011

- d2: at day 180 in 2012

FIGURE 1: Effects of FGDB application on soil pH values for 2011 and 2012 (mean \pm standard deviation of triplicate measurements. T0: control, T1: $4.50 \mathrm{t} \cdot \mathrm{hm}^{-2}$, T2: $9.00 \mathrm{t} \cdot \mathrm{hm}^{-2}$, T3: $13.50 \mathrm{t} \cdot \mathrm{hm}^{-2}$, and T4: $18.00 \mathrm{t} \cdot \mathrm{hm}^{-2}$. Lowercase letters denote statistically significant differences across treatments $(P \leq 0.05)$ in 2011 and 2012, respectively. soils to a certain extent at the end of the experiment in 2011. Within the first year of application, at $0-10 \mathrm{~cm}$ depth, EC increased in response to FGDB addition. The average EC values in all the four treatments were higher than those of the control. In 2011, EC values for soils amended with FGDB increased from 0.44 to $0.46 \mathrm{mMho} \mathrm{cm}^{-1}$ at the $\mathrm{T} 1$ rate, to $0.49 \mathrm{mMho} \mathrm{cm}^{-1}$ at the T2 rate, to $0.51 \mathrm{mMho} \mathrm{cm}^{-1}$ at the

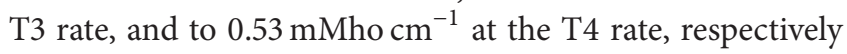
(Table 8). When compared to the initial ECe value in 2011, the average value in 2012 was decreased to $0.41,0.44,0.46$, and $0.51 \mathrm{mMho}^{-1}$ for T1, T2, T3, and T4, respectively. Due to the bigger precipitation in 2012, more soluble salts leached into deeper soil profile resulting in the decrease of EC values compared with that of 2011. EC values of 0.5 to 1.0 can reduce germination and cause burning or wilting in some sensitive crops [35]. So, higher application rate of FGDB may influence potential growth of crops. 
3.6. ESP. Due to the excess exchangeable sodium, the initial ESP of the test soil is very high, 16.34. Soluble salts in FGDB were dispersed into soil and the exchangeable sodium was replaced by soluble calcium. Other substances in FGDB, such as sulphuric acid and sulphur, indirectly through chemical or biological action make the relatively insoluble calcium carbonate which commonly existed in alkaline soils available for replacement of sodium. The maximum exchangeable sodium percentage decrease was in case of T3, that is, $8.48 \%$ followed by T4 (9.40\%), T2 (10.24\%), and T1 (11.56\%). As a result, the concentration of $\mathrm{Na}$ decreased, and the ESP values decrease synchronously with the decrease of soil $\mathrm{pH}$ values (Table 8). Compared with the control, supply of inherent calcium from the FGDB is likely to further accelerate the decrease process of ESP.

3.7. FGDB to Improve Plant Nutrients. Addition of FGDB to soil had some positive effect on nutrients status and other chemical parameters. Chemically, FGDB contains some growth-essential elements like $\mathrm{K}, \mathrm{Ca}$, and $\mathrm{S}$ which promote plant growth and also alleviate the condition of nutrient deficient soils. As calcium sulfate $\left(\mathrm{CaSO}_{4}\right)$ is the major constituent of FGDB, additional components, including $\mathrm{Na}_{2} \mathrm{O}$, $\mathrm{K}_{2} \mathrm{O}, \mathrm{MgO}, \mathrm{Cl}$, and $\mathrm{P}_{2} \mathrm{O}_{5}$, contribute largely to the nutrient resources of the FGDB amended soils. The soil was poor in organic $\mathrm{C}, \mathrm{N}$, and $\mathrm{P}$ contents. The addition of FGDB profoundly affected the cation and anion concentrations (Table 8). Similar progressive changes with respect to the rate of application were observed. Concentrations of calcium, sodium, and available phosphorus increased with respect to higher FGDB application. However, organic carbon, nitrate nitrogen, and potassium contents of soil decreased with the higher amendments of FGDB. The available P contents of the soils increased with an increase in the quantity of FGDB application due to the relatively high content of available $\mathrm{P}$ in the FGDB. The FGDB contained about $1120 \mathrm{mg} \mathrm{kg}^{-1}$ of available $\mathrm{P}_{2} \mathrm{O}_{5}$ (Table 5). Around 50.40, 100.8, 151.2, and $201.6 \mathrm{~kg} \mathrm{hm}^{-2}$ of available $\mathrm{P}_{2} \mathrm{O}_{5}$ were supplied by the application of T1, T2, T3, and T4, respectively. Usually, FGDB contains a small quantity of organic matter and $\mathrm{N}$; thus, there was an insignificant increase in available $\mathrm{N}$ in all the four FGDB amended soils in comparison to the control soil.

Concentrations of $\mathrm{Cl}^{-}, \mathrm{SO}_{4}{ }^{2+}, \mathrm{Ca}^{2+}$, and $\mathrm{K}^{+}$were greater in the FGDB amended soils compared with the control. $\mathrm{Ca}^{2+}$ concentrations in 2012 were greater in FGDB amended soils compared to those of 2011, reflecting a successive increase in $\mathrm{Ca}^{2+}$ concentration in soil amended with FGDB for 2 years compared with the control soil and the soil amended with FGDB for 1 year (Table 8). Similarly, total N contents increased progressively by up to $60 \%$ in 2011 and $73 \%$ in 2012, respectively, in response to FGDB addition. Other soil chemical parameters were not affected by FGDB addition. FGDB has both the soil amending and nutrient-enriching properties and is helpful in improving crop growth and yield in low fertility alkaline clay-rich soils.

\subsection{The Effects on the Germination Percentage, Plant Height, and Crop Yield}

3.8.1. Germination Percentage. Seedlings were monitored by calculating seed germination percentages 2 weeks after planting. At day 15 , all the plant has germinated and counted the percentage of germination. Germination percentage was higher under all the four different FGDB treatments as compared to the control (Table 9). Germination percentage was maximum in treatment T3 in both years. It was 79.02\% in 2011 and $91.25 \%$ in 2012 , respectively. It was significantly more as compared to control. Treatments T1, T2, and T4 significantly increased the germination percentage as compared to the control (T0), yet it was lesser than the germination percentage in treatment $\mathrm{T} 3$.

3.8.2. Plant Height. It is evident from Table 9 that because of the increase in the dosage of FGDB from 4.5 to $13.5 \mathrm{thm}^{-2}$, the plant height of maize increased significantly $(P \leq 0.05)$ and progressively in the range from 13.71 to $29.09 \%$ in 2011 and $14.68 \%$ to $32.74 \%$ over the control (T0). The plant height increase in all the FGDB amended plots was significantly $(P \leq$ $0.05)$ higher than the control. The increase of plant height in treatment T3 was significantly $(P \leq 0.05)$ greater than all other FGDB treatments (Table 9). The results indicated that higher FGDB application rates of T4 may retard growth of plant height when compared with application rates of T3. Even at the highest level treatments, however, little negative effects on the plant growth and no symptoms of toxicity were noticed. Hence, the optimum dosage of FGDB is $13.5 \mathrm{thm}^{-2}$ for test site and crop species. The adverse effect of the application of higher dosages of FGDB (beyond $13.5 \mathrm{thm}^{-2}$ ) was observed to retard growth of plant height. In general, the addition of FGDB stimulated the increase of plant height.

3.8.3. Crop Yield. Similar to the plant heights, crop yield was also affected by FGDB treatments. In the first year, after harvesting at day 180 , the yield of maize was maximum in treatment $\mathrm{T} 3$ followed by $\mathrm{T} 2$, $\mathrm{T} 4$, and $\mathrm{T} 1$, respectively, and the increase was significantly more than the control. The changes in crop yield are shown in Table 9. The addition of $\mathrm{T} 1, \mathrm{~T} 2, \mathrm{~T} 3$, and $\mathrm{T} 4$ resulted in $23.0 \%, 34.5 \%, 44.4 \%$, and $32.58 \%$ increase in the crop yield in 2011, respectively. In 2012 , the crop yield increase at $49.9 \%, 50.9 \%, 59.8 \%$, and $37.8 \%$, compared with the control, respectively. The increases in these four treatments were comparable to each other. Similarly, caused by the cumulative effects of FGDB, the yield of the second year has a slight increase comparable to the yields of the first year, respectively. All the four soil amendment treatments significantly improved crop yield when compared with the controls. The improved crop yield possibly was from a decrease in soil $\mathrm{pH}$ value and associated changes in soil particle size and other physical properties. The significantly greater average growth parameters and yield in subplots with FGDB application demonstrated that FGDB has the potential to improve crop plant growth and yield in alkaline soils. 
TABLE 9: Effect of FGDB on germination percentage, plant height, and crop yield during two cropping years.

\begin{tabular}{ccccccc}
\hline & \multicolumn{2}{c}{ Germination percentage (\%) } & \multicolumn{2}{c}{ Plant height $(\mathrm{cm})$} & \multicolumn{2}{c}{${\text { Crop yield }\left(\mathrm{kg} \cdot \mathrm{hm}{ }^{-2}\right)}^{2}$} \\
& 2011 & 2012 & 2011 & 2012 & 2011 & 1012 \\
\hline T0 & $56.34 \pm 1.89^{\mathrm{c}}$ & $60.23 \pm 1.45^{\mathrm{c}}$ & $105.26 \pm 1.56^{\mathrm{c}}$ & $108.31 \pm 1.47^{\mathrm{c}}$ & $827.65 \pm 32.76^{\mathrm{c}}$ & $1050.15 \pm 44.82^{\mathrm{d}}$ \\
T1 & $62.35 \pm 1.09^{\mathrm{b}}$ & $69.97 \pm 1.78^{\mathrm{b}}$ & $119.70 \pm 3.41^{\mathrm{b}}$ & $124.21 \pm 2.96^{\mathrm{b}}$ & $1018.22 \pm 43.13^{\mathrm{b}}$ & $1574.17 \pm 53.56^{\mathrm{b}}$ \\
T2 & $64.87 \pm 2.15^{\mathrm{b}}$ & $71.11 \pm 1.33^{\mathrm{b}}$ & $124.51 \pm 2.94^{\mathrm{b}}$ & $129.45 \pm 2.57^{\mathrm{b}}$ & $1113.47 \pm 42.10^{\mathrm{a}}$ & $1584.47 \pm 25.16^{\mathrm{b}}$ \\
T3 & $79.02 \pm 3.07^{\mathrm{a}}$ & $91.25 \pm 2.27^{\mathrm{a}}$ & $138.52 \pm 1.30^{\mathrm{a}}$ & $154.52 \pm 1.30^{\mathrm{d}}$ & $1195.56 \pm 36.47^{\mathrm{a}}$ & $1678.06 \pm 32.28^{\mathrm{a}}$ \\
T4 & $77.50 \pm 2.89^{\mathrm{a}}$ & $88.32 \pm 2.56^{\mathrm{a}}$ & $135.89 \pm 2.24^{\mathrm{a}}$ & $143.78 \pm 2.14^{\mathrm{a}}$ & $1097.36 \pm 53.28^{\mathrm{b}}$ & $1446.98 \pm 40.72^{\mathrm{c}}$ \\
\hline
\end{tabular}

Letters denote statistically significant differences across treatments $(P \leq 0.05)$.

\section{Discussion}

There are two main aspects to consider when evaluating the efficacy of FGDB as soil amendment materials. One is the ability of the material to neutralize soil alkalinity and lower high soil $\mathrm{pH}$ values; the other is the ability to improve soil fertility and enhance the growth and yield of crops.

The agronomic benefit of FGDB applications is primarily associated with improved physicochemical characteristics of the soil. Application of FGDB can reduce clay dispersion and force clay particles into microaggregates; hence, the silt content increased eventually, and better soil texture gradually formed. Bulk density is an indicator of both pore space and solid particles within the profile and provides an indication of water holding capacity and amount of organic matter present. The amendments had some positive effects on the bulk density, because FGDB is generally considered to enhance aggregation, thus reducing bulk density. FGDB with its low bulk density is a suitable additive to improve the bulk density of soils in a mixture. So reductions in bulk density can be attributed to an increase in aggregate content as a result of the FGDB applications. The increase in aggregate content is due to the changes in packing patterns which occur when particles of different size classes are mixed together. FGDB amended soils have less bulk density and greater water holding capacity, compared with non-FGDB amended soil. It means that FGDB has similar function of fly ash, which is reported to have the function of relieving surface crusting and compaction, increasing water infiltration and holding capacity, and improve aggregate stability.

The FGDB addition alters soil physical properties such as its texture, bulk density, water holding capacity [24], and particle size distribution [36]. Campbell et al. (1983) found that FGDB addition at the rate of $10 \%$ increased the water holding capacity 7.2 and 413.2 times for fine and coarse sands, respectively [37].

Soil salinity is measured as electrical conductivity (EC). As EC is a quantitative measure of the presence of cations and anions in the soil, FGDB enriched with several cations and anions, on addition to the normal soils, enhanced electrical conductivity of FGDB amended soils significantly.

Due to the better solubility of FGDB by mixing it with soils surface $15 \mathrm{~cm}$ soil, was more effective in the removal of exchangeable sodium than FGDB applied on the soil surface. Sodium salts in the alkaline soil are diluted by the application of FGDB that nearly complete displacement of exchangeable sodium by calcium from the FGDB solution occurs. Application of FGDB at different rates decreased the soil $\mathrm{pH}$ and ESP, while it increased EC of the alkaline soil at the time of sowing of maize. The amended soils showed a relatively significant decrease in $\mathrm{pH}$ and ESP following increased applications of the FGDB. The soil improvement caused by the amendment made conditions more favorable for plant growth.

A correlative relationship between soil $\mathrm{pH}$ and the exchangeable sodium percentage for some sodic soils has been pointed out earlier. It means ESP values have a similar change trend to soil $\mathrm{pH}$. The decrease in $\mathrm{pH}$ and ESP during reclamation of alkaline soils can be explained due to the replacement of exchangeable $\mathrm{Na}^{+}$ions with $\mathrm{Ca}^{2+}$, which is an important mechanism in decreasing $\mathrm{pH}$ during reclamation of alkaline soils [38]. For alkali soils, Sakai (2004) found that the amended soils showed a decrease in $\mathrm{pH}$ from 10.5 to 9.5 after addition of FGDB [8]. Increase in EC and moisture retaining field capacity were reported in fly ash amended soils for maize [39]. Thus, FGDB also can be considered as an effective liming agent to neutralize solution $\mathrm{pH}$ and reduce exchangeable alkalinity values.

The available nutrients in the FGDB amended soil could satisfy the growth demand of plants, and the $\mathrm{pH}$ tended to neutrality. Addition of FGDB to soil in the present study has been proved to have some positive effect on nutrients status and other chemical parameters. According to M. R. Khan and M. W. Khan, a gradual increase in FGDB concentrations in the normal field soil improved the availability of sulfate, carbonate, bicarbonate, chloride, $\mathrm{P}, \mathrm{K}, \mathrm{Ca}, \mathrm{Mg}, \mathrm{Mn}, \mathrm{Cu}, \mathrm{Zn}$, and B [40]. FGDB has successfully been used to quickly reduce $\mathrm{Na}^{+}$concentrations during the reclamation of sodic soils. The results of the present study confirm the findings of earlier works showing decrease in $\mathrm{Na}^{+}$concentrations with increase of FGDB incorporation [41]. Better growth and yield may be due to the presence of some utilizable plant nutrients such as sulphate, $\mathrm{P}, \mathrm{K}$, and $\mathrm{Ca}$ in FGDB because field soil used in the experiment was low on plant nutrients especially $\mathrm{P}$ and K.

There is no clear guidance we can follow with regard to the application rate of FGDB as soil amendment. The FGDB significantly increased some important plant macronutrients; the possibility exists that, at a rational rate of application, crop yield increase can be attained in FGDB amended soils. FGDB in heavy dose may have some potential adverse effect on plant growth. Addition of FGDB to soil up to $13.5 \mathrm{t} / \mathrm{hm}^{2}$ was beneficial for growth and yield of maize and the physical and chemical properties of test soil, above which it has 
an adverse effect on both growth and yield of maize. The problem may not limit the potential use of FGDB with crops. However, more emphasis should be paid to the optimum application rate of FGDB with certain soil and certain crop species and how well the crop can withstand the potential deleterious effects.

The FGDB was beneficial to plant growth if applied to alkaline soil at appropriate levels. In the present study, treatments having FGDB as a soil amendment demonstrated that FGDB applications had a positive impact on average yield and germination percentage and plant height. The results indicated that the growth parameters like germination percentage and plant height increased with the four different FGDB application rates. The optimum dosage of FGDB is $13.5 \mathrm{t} / \mathrm{hm}^{2}$ to the test crop, maize. Treatment with above $13.5 \mathrm{thm}^{-2}$ FGDB as soil amendment showed an adverse effect on the plant growth by retarding the plant height. Mittra et al. (2005) observed better growth of rice plants grown on soil amended with FGDB at lower concentrations [42]. Singh et al. (1997) found that higher FGDB application either delays or drastically inhibits plant growth, development, and other specific parameters. The retarded growth of plants grown with higher concentrations of FGDB amended soil was reflected by slow growth as well as grain yield [43].

According to the previous experiments, both in field and greenhouse conditions showed that different rates of FGDB can promote plant growth and improve the agronomic properties of the soils $[13,16]$. Due to the improved agronomic soil properties, crop usually grows more readily in FGDB amended soils. Enhanced growth with application of FGDB has been reported in many plants [17]. Growth of a new planting of alfalfa (Medicago sativa L.) was increased by 10 to $40 \%$ by the treatments compared to the untreated control [44]. As an industrial waste, the availability of FGDB can be a supply of nonconventional sources of plant nutrients and soil conditioners and can be utilized for increasing crop yield and can help to improve the environment and ecology as the waste can be utilized for enhancing yield and will also help to solve the disposal problem of wastes. In China, use of these large quantities of FGDB in agricultural land not only improves the physical and chemical fertility of soils but also resolves industrial waste disposal problem.

\section{Conclusion}

Application of FGDB as an alkaline soil amendment positively boosted the soil quality by improving its physical and chemical properties. Based on the results, compared to zero application of FGDB, treatments modified significantly the soil physical (soil texture, bulk density, and water holding capacity) and chemical (soil pH and EC and plant nutrients) properties at field scale. These modifications finally clearly affected some selected soil physiochemical properties and crop growth parameters including germination percentage, plant height, and crop yield of maize. Of all 4 different treatments, we obtained the most positive effect at the rate of $13.5 \mathrm{thm}^{-2}$ treatment T3. The physical benefits of the soil include improved soil texture due to the addition of silt-sized
FGDB that promoted better soil mechanical composition, water holding capacity, and bulk density. Chemical benefits may be due to the presence of essential plant nutrients for crop production or the supply of a more favorable substrate for plant growth by modifying the soil. The liming capacity of the FGDB makes it suitable for decreasing $\mathrm{pH}$ in alkaline soils. FGDB also has beneficial effects on maize growth which is attributed to its ability to supply essential plant nutrients. Its addition to soil resulted in agronomic benefits enabling raising germination percentage, plant height, and crop yield and even growing of crops on nutrient deficient soils and can be successfully used to correct the soil $\mathrm{pH}$ values.

Our results confirmed that FGDB can be successfully used to buffer alkaline soils and adjust soil $\mathrm{pH}$ to a suitable range that optimizes the availability of most of the plant nutrients. However, in future studies, a long-term experiment should be carried out to assess the ecological safety effects of agricultural use of FGDB even at low doses.

\section{Conflict of Interests}

The authors declare that there is no conflict of interests regarding the publication of this paper.

\section{Acknowledgments}

This study was financially supported by the open program from the State Key Laboratory of Earth Surface Process and Resource Ecology (Grant no. 2010-KF-07) and by the National Natural Science Foundation of China Program (Grant no. 41261068). The authors are thankful to Ms. Linhong $\mathrm{Wu}$ for providing valuable help in collecting and analyzing soil samples.

\section{References}

[1] G. I. Metternicht and J. A. Zinck, "Remote sensing of soil salinity: potentials and constraints," Remote Sensing of Environment, vol. 85, no. 1, pp. 1-20, 2003.

[2] M. P. Reddy, M. T. Shah, and J. S. Patolia, "Salvadora persica, a potential species for industrial oil production in semiarid saline and alkali soils," Industrial Crops and Products, vol. 28, no. 3, pp. 273-278, 2008.

[3] J. Y. Li, J. He, and J. Wang, "Safety evaluation index system of blackish water irrigation," Journal of China Rural Water and Hydropower, no. 8, pp. 8-12, 2010 (Chinese).

[4] Y. Sakai, S. Shitara, and M. Sadakata, "Salts transport in alkali soil reclamation by gypsum and prediction of Na leaching in field in China," Journal of Water and Environment Technology, vol. 7, no. 2, pp. 121-133, 2009.

[5] American Coal Ash Association, "The changing face of the utility industry and its impact on coal combustion by-product management," in Proceedings of the 12th International Symposium on Management and Use of Coal Combustion by-Products, pp. 26-30, American Coal Ash Association, Orlando, Fla, USA, January 1997.

[6] R. K. Srivastava, W. Jozewicz, and C. Singer, " $\mathrm{SO}_{2}$ scrubbing technologies: a review," Environmental Progress, vol. 20, no. 4, pp. 219-227, 2001. 
[7] M. Ahmaruzzaman, "A review on the utilization of fly ash," Progress in Energy and Combustion Science, vol. 36, no. 3, pp. 327-363, 2010.

[8] Y. Sakai, S. Matsumoto, and M. Sadakata, "Alkali soil reclamation with flue gas desulfurization gypsum in China and assessment of metal content in corn grains," Soil and Sediment Contamination, vol. 13, no. 1, pp. 65-80, 2004.

[9] F. E. Rhoton and D. S. McChesney, "Influence of FGD gypsum on the properties of a highly erodible soil under conservation tillage," Communications in Soil Science and Plant Analysis, vol. 42, no. 16, pp. 2012-2023, 2011.

[10] L. Chen, R. Stehouwer, M. Wu et al., "Minesoil response to reclamation by using a flue gas desulfurization product," Soil Science Society of America Journal, vol. 77, no. 5, pp. 1744-1754, 2013.

[11] M. E. Buckley and R. P. Wolkowski, "In-season effect of flue gas desulfurization gypsum on soil physical properties," Journal of Environmental Quality, vol. 43, no. 1, pp. 322-327, 2014.

[12] T. M. DeSutter, L. J. Cihacek, and S. Rahman, "Application of flue gas desulfurization gypsum and its impact on wheat grain and soil chemistry," Journal of Environmental Quality, vol. 43, no. 1, pp. 303-311, 2014.

[13] S. Dwivedi, R. D. Tripathi, S. Srivastava et al., "Growth performance and biochemical responses of three rice (Oryza sativa L.) cultivars grown in fly-ash amended soil," Chemosphere, vol. 67, no. 1, pp. 140-151, 2007.

[14] A. Singh, R. K. Sharma, and S. B. Agrawal, "Effects of fly ash incorporation on heavy metal accumulation, growth and yield responses of Beta vulgaris plants," Bioresource Technology, vol. 99, no. 15, pp. 7200-7207, 2008.

[15] V. C. Pandey and N. Singh, "Impact of fly ash incorporation in soil systems," Agriculture, Ecosystems \& Environmen, vol. 136, no. 1-2, pp. 16-27, 2010.

[16] A. Singh and S. B. Agrawal, "Response of mung bean cultivars to fly ash: growth and yield," Ecotoxicology and Environmental Safety, vol. 73, no. 8, pp. 1950-1958, 2010.

[17] S. Jala and D. Goyal, "Fly ash as a soil ameliorant for improving crop production-a review," Bioresource Technology, vol. 97, no. 9, pp. 1136-1146, 2006.

[18] K. Dontsova, Y. B. Lee, B. K. Slater, and J. M. Bigham, Gypsum for Agricultural Use in Ohio: Sources and Quality of Available Products, Ohio State University School of Natural Resources, 2005.

[19] D. M. Endale, H. H. Schomberg, D. S. Fisher, D. H. Franklin, and M. B. Jenkins, "Flue gas desulfurization gypsum: implication for runoff and nutrient losses associated with broiler litter use on pastures on ultisols," Journal of Environmental Quality, vol. 43, no. 1, pp. 281-289, 2014.

[20] H. Lee, H. S. Ha, C. H. Lee, Y. B. Lee, and P. J. Kim, "Fly ash effect on improving soil properties and rice productivity in Korean paddy soils," Bioresource Technology, vol. 97, no. 13, pp. 14901497, 2006.

[21] G. L. Terman, V. J. Kilmer, C. M. Hunt, and W. Buchanan, "Fluidized bed boiler waste as a source of nutrients and lime," Journal of Environmental Quality, vol. 7, no. 1, pp. 147-150, 1978.

[22] J. T. Crews and W. A. Dick, "Liming acid forest soils with flue gas desulfurization by-product: growth of Northern red oak and leachate water quality," Environmental Pollution, vol. 103, no. 1, pp. 55-61, 1998.

[23] M. E. Schutter and J. J. Fuhrmann, "Soil microbial community responses to fly ash amendment as revealed by analyses of whole soils and bacterial isolates," Soil Biology and Biochemistry, vol. 33, no. 14, pp. 1947-1958, 2001.

[24] A. C. Chang, L. J. Lund, A. L. Page, and J. E. Warneke, "Physical properties of fly ash amended soils," Journal of Environmental Quality, vol. 6, no. 3, pp. 267-270, 1977.

[25] R. B. Clark, K. D. Ritchey, and V. C. Baligar, "Benefits and constraints for use of FGD products on agricultural land," Fuel, vol. 80, no. 6, pp. 821-828, 2001.

[26] Y. Zhang, E. Kendy, Y. Qiang, L. Changming, S. Yanjun, and S. Hongyong, "Effect of soil water deficit on evapotranspiration, crop yield, and water use efficiency in the North China Plain," Agricultural Water Management, vol. 64, no. 2, pp. 107-122, 2004.

[27] Y. B. Lin, Experimental study on the amelioration of coastal salt-affected soils in north China based on winter brackish ice mulching [Dissertation], Beijing Normal University, Beijing, China, 2011.

[28] A. L. Black and J. F. Power, "Effect of chemical and mechanical fallow methods on moisture storage, wheat yields, and soil erodibility," Soil Science Society of America, vol. 29, no. 4, pp. 465-468, 1965.

[29] M. Guo, N. Tongtavee, and M. Labreveux, "Nutrient dynamics of field-weathered delmarva poultry litter: implications for land application," Biology and Fertility of Soils, vol. 45, no. 8, pp. 829838, 2009.

[30] U.S. EPA, Method 3050. Acid Digestion of Sediments, Sludges, Soils and Oils. SW-846, U.S. EPA, Washington, DC, USA, 1996.

[31] N. Koukouzas, C. Ketikidis, and G. Itskos, "Heavy metal characterization of CFB-derived coal fly ash," Fuel Processing Technology, vol. 92, no. 3, pp. 441-446, 2011.

[32] B. Wang, G. J. Xiao, G. L. Mao, Z. H. Yue, and X. Xu, "coal-fired flue gas desulfurated waste residue application on salinealkali soil amelioration and oil-sunflower growth," Chinese Journal of Plant Ecology, vol. 34, no. 10, pp. 1227-1235, 2010, (in Chinese with English abstract).

[33] U.S. EPA, "Standards for the use or disposal of sewage sludge: final rules," Federal Register, vol. 58, 40 CFR Parts 503, Subpart D, pp. 9398-9400, 1993.

[34] P. Asokan, M. Saxena, and S. R. Asolekar, "Coal combustion residues-environmental implications and recycling potentials," Resources, Conservation and Recycling, vol. 43, no. 3, pp. 239-262, 2005.

[35] Council on Soil Testing and Plant Analysis, Handbook on Reference Methods for Soil Analysis, Soil and Plant Analysis Council, Athens, Ga, USA, 1992.

[36] S. Sharma, M. H. Fulekar, and C. P. Jayalakshmi, "Fly ash dynamics in soil-water systems," Critical Reviews in Environmental Control, vol. 19, no. 3, pp. 251-275, 1989.

[37] D. J. Campbell, W. E. Fox, R. L. Aitken, and L. C. Bell, "Physical characteristics of sands and amended with fly-ash," Australian Journal of Soil Research, vol. 21, no. 2, pp. 147-154, 1983.

[38] S. Gaind and A. C. Gaur, "Quality assessment of compost prepared from fly ash and crop residue," Bioresource Technology, vol. 87, no. 1, pp. 125-127, 2003.

[39] N. Kalra, M. C. Jain, H. C. Joshi et al., "Soil properties and crop productivity as influenced by flyash incorporation in soil," Environmental Monitoring and Assessment, vol. 87, no. 1, pp. 93109, 2003.

[40] M. R. Khan and M. W. Khan, "The effect of fly ash on plant growth and yield of tomato," Environmental Pollution, vol. 92, no. 2, pp. 105-111, 1996. 
[41] E. Amezketa, R. Aragüés, and R. Gazol, "Efficiency of sulfuric acid, mined gypsum, and two gypsum by-products in soil crusting prevention and sodic soil reclamation," Agronomy Journal, vol. 97, no. 3, pp. 983-989, 2005.

[42] B. N. Mittra, S. Karmakar, D. K. Swain, and B. C. Ghosh, "Fly ash-a potential source of soil amendment and a component of integrated plant nutrient supply system," Fuel, vol. 84, no. 11, pp. 1447-1451, 2005.

[43] S. N. Singh, K. Kulshreshtha, and K. J. Ahmad, "Impact of fly ash soil amendment on seed germination, seedling growth and metal composition of Vicia faba L," Ecological Engineering, vol. 9, no. 3-4, pp. 203-208, 1997.

[44] L. Chen, W. A. Dick, and S. Nelson Jr., "Flue Gas Desulfurization products as sulfur sources for alfalfa and soybean," Agronomy Journal, vol. 97, no. 1, pp. 265-271, 2005. 

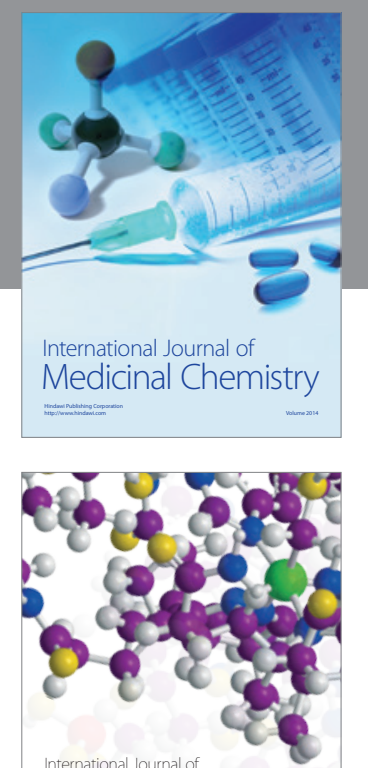

\section{Carbohydrate} Chemistry

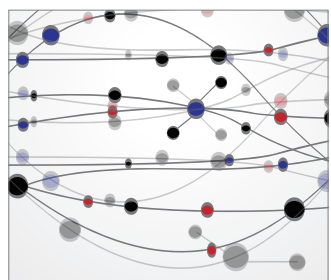

The Scientific World Journal
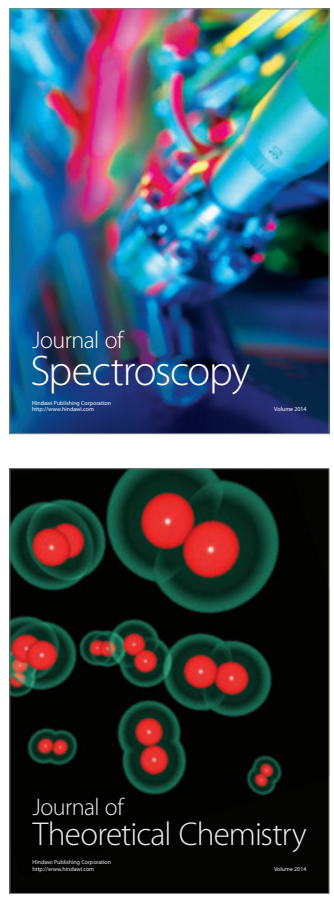
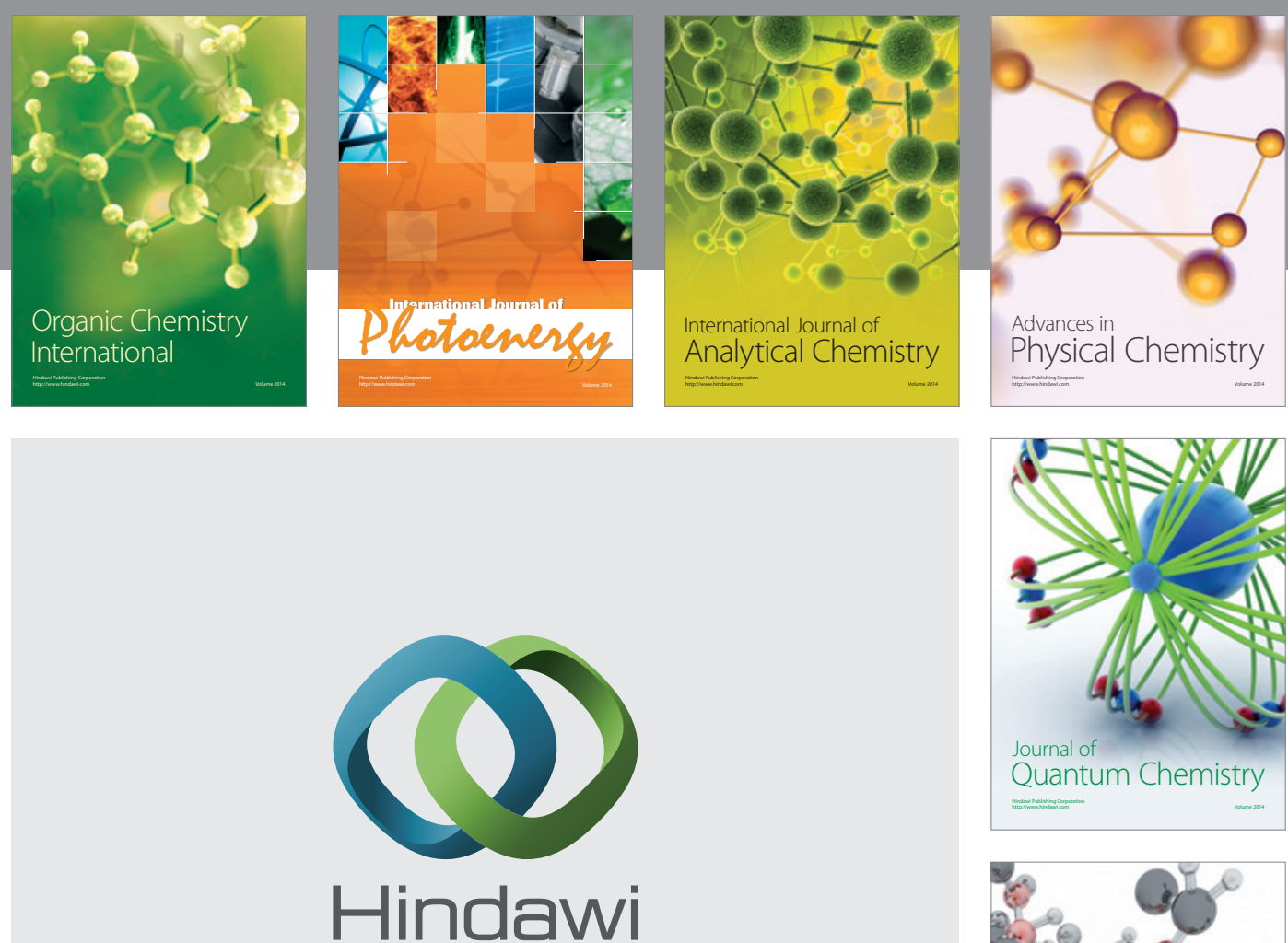

Submit your manuscripts at

http://www.hindawi.com

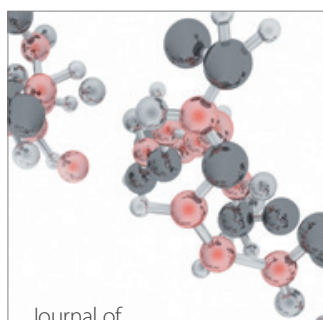

Analytical Methods

in Chemistry

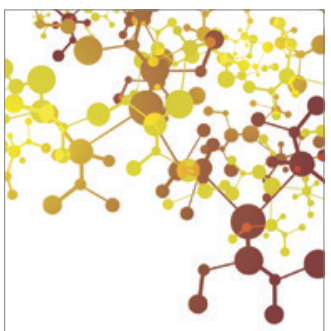

Journal of

Applied Chemistry

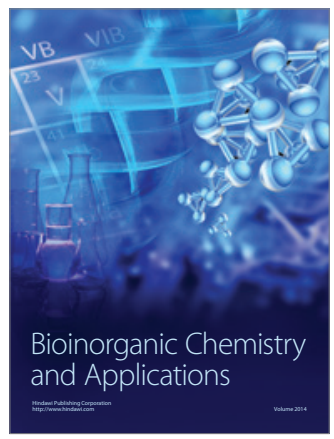

Inorganic Chemistry
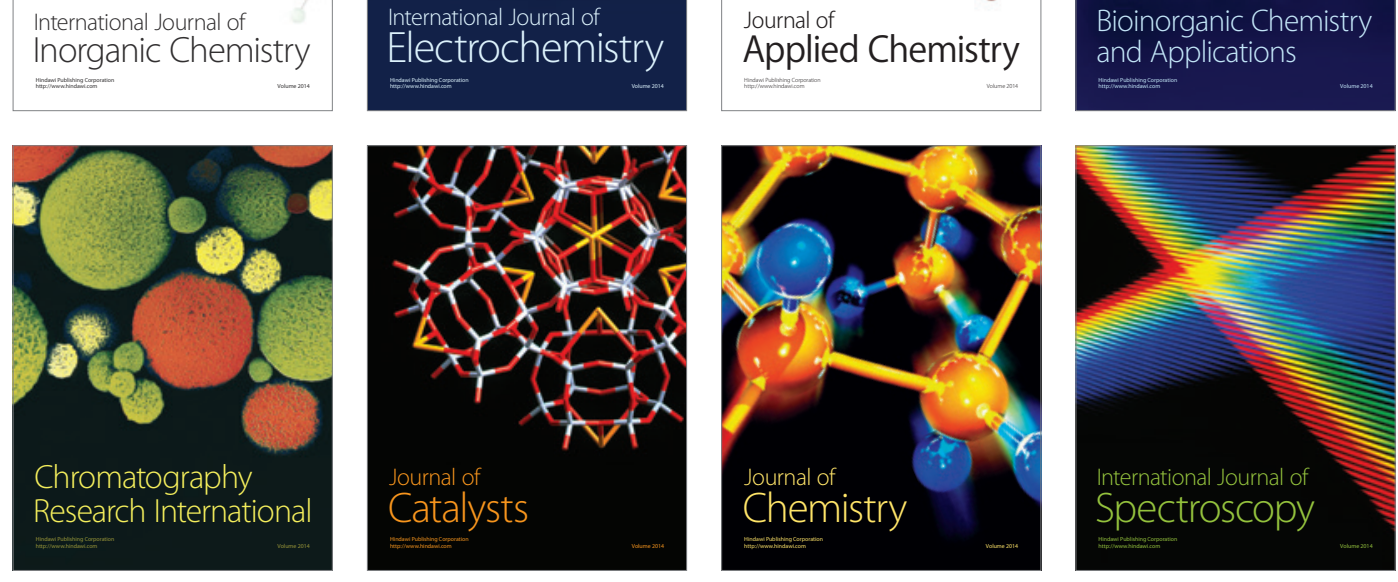